\title{
STUDENTS' WELL-BEING AND GAME IMPLEMENTATION IN LEARNING CHEMISTRY IN MERDEKA BELAJAR ERA
}

\section{Ni'matul Zahro $^{1}$, Achmad Lutfi ${ }^{2}$}

1,2 Jurusan Kimia FMIPA Universitas Negeri Surabaya, Surabaya, Indonesia

\author{
A R T I C L E I N F 0 \\ Article history: \\ Received 29 November 2020 \\ Received in revised form 19 \\ December 2020 \\ Accepted 20 January 2021 \\ Available online 25 April 2021
}

Keywords

Merdeka Belajar

Students' Well-being,

Games

\begin{abstract}
A B S T R A K
Students' well-being takes a primary role. Innovation to enhance students' well-being is game implementation as learning media. This research aims to discover students' well-being consequences on students' academic performance in learning chemistry in Merdeka Belajar era, know students' academic performance enhancement after game implementation as learning media in Merdeka Belajar era, and know students' responses in games implementation as learning media in Merdeka Belajar era. This study uses One Group Pretest-Posttest Design with $33 \mathrm{XI}-\mathrm{MIA}$ students at high school as a research subject. Instruments used in this study were student well-being questionnaire, student pretest-posttest sheets, and student response questionnaire. Student well-being questionnaires result before and after game implementation was tested correlation resulting significance value 0.043 and correlation coefficient 0.36 . The pretest and posttest students' outcomes were tested by paired sample T-test significance $5 \%$ resulting significance value 0.002 . The students' responses result is $\geq 60 \%$ in agreement. Then it can be summed up that implementation of the game as a learning media can develop the well-being of students.
\end{abstract}

\section{Introduction}

The outbreak of the Covid-19 pandemic in Indonesia is quite influential in several sectors including education. The Ministry of Education and Culture (Kemendikbud) creates a Learning from the Home policy so that it can be an option for implementation learning (Kristiawan et al., 2021; Wilson, 2020). This policy is implemented to follow the WHO (World Health Organization) health protocol namely physical distancing to cut off the spread of the Covid-19 virus. In its implementation, there are new strategies applied in the teaching and learning process, namely E-learning based education. Process E-learning-based teaching and learning requires teachers, lecturers, participant students, and students to adapt to the challenges of the times and more maximize technology (Müller et al., 2021; Tauhid et al., 2020). Therefore was initiated an innovation to make a change in the field of education, namely the concept of independent learning (Susilana et al., 2020). The concept of Merdeka Belajar was formulated by the Minister of Education and Culture (Mendikbud), Nadiem Makarim to make it happen to learn in a refreshing, interesting, and happy atmosphere (Abidah et al., 2020). Merdeka Belajar means freedom in learning that can be intended to provide flexibility for students to study anywhere and anytime without stress and demands with a focus on the natural talent they have. That way, students can learn optimally and develop their interests and talents as much as possible.

The Merdeka Belajar policy is an alternative to realizing learning that does not put pressure on students. Thus, students feel happy and prosperous to get knowledge and experience at its best considering the conditions of the Covid-19 pandemic. The well-being of students is the most important concern for schools because it is based on the formulation of The Australian Council for Educational Research, the wellbeing of students is related to the level of effectiveness of the function students in the school community (Fraillon, 2004), play a major role in learning and influencing the optimization of the functions of students in the school. Well-being at school as important factors for students that can affect the learning process (Lau \& Hue, 2011). The positive influence is shown by the well-being of students, for example, students can show positive and healthy behavior (Awartani et al., 2008). Increased well-being of students can improve 
academic achievement, either directly or indirectly. For example, a higher level of well-being positively affects academic achievement by increasing motivation, engagement, attendance, and reducing problem behavior (Hasan \& Bao, 2020; Rasmitadila et al., 2019). The operational measurement model for the wellbeing of students in the school community must have two dimensions, namely the interpersonal dimension and intrapersonal dimension. The interpersonal dimension of the well-being of learners includes those aspects of well-being that are only proven through interaction with someone, or a response to another. Four-dimensional aspects of the interpersonal well-being of learners in the school community are communicative effectiveness, empathy, acceptance, and connectedness. The intrapersonal well-being of students includes several aspects of well-being that prioritizes the sense in yourself and the capacity of students internalized to function within their school community. There are nine aspects of the intrapersonal dimension of the well-being of learners in the community schools are as follows: spirituality, resilience, curiosity, self-efficacy, emotional regulation, autonomy, involvement, mastery orientation, and self-esteem (Fraillon, 2004).

This research is limited to the aspects of self-efficacy and curiosity included in the intrapersonal dimension of student well-being. Self-efficacy as an individual's assessment of proficiency to tackle and finish learning with steps to achieve the performance that has been declared (Bandura, 2006). Bandura believes in self-efficacy and plays an important role in regulating the motivation of students. High selfefficacy can make people reach goals well (Stajkovic \& Luthans, 1998). Besides, people with higher selfefficacy will work more optimally when compared with people who have efficacy low. Bandura (2006) asserts that academic self-efficacy is students' self-confidence in their ability to succeed in learning and doing academic work. Based on previous research, that the majority of students' self-efficacy levels were in a good category, namely with a percentage of achievement of $66.64 \%$, which means that the level of student confidence in their abilities was equal to that percentage (Nuraeni et al., 2019). A study on SMA XI students in Banjarmasin and found that the self-efficacy of SMAN 2 students was better than students of SMAN 6, SMAN 8, SMAN 12 because they got the highest result, namely 75.5\% (Naparin et al., 2020). Curiosity is a powerful motivating force manifested by its capacity to energize and control direction learning behavior such as information seeking and problem-solving (Litman \& Jimerson, 2004). In the context of school, curiosity will be manifested by the capacity of learners to engage with school-based assignments regardless of perceptions of external rewards and to design and focus on strategy to explore learning. Although curiosity has motivated positively correlated with academic achievement (Alberti \& Witryol, 1994; CahillSolis \& Witryol, 1994) evidence of curiosity in the school context is forthcoming from the process rather than the results of the completion of student tasks. Based on the research results in XI MIA 2 students of SMA Negeri 2 Surakarta, the level of curiosity of students was 64.3\% (Pamungkas et al., 2017). Besides, other research results state that the percentage of curiosity for XI MIA students is 65\% (Prihastoto et al., 2019).

Another way to involve children in learning is through the inclusion of ICT (Information and Communication Technology) in the classroom (Alsumait \& Al-Musawi, 2013). Digitizing the learning process, not only students but also teachers can improve their skills with the same goal of creating a more attractive and effective educational process. ICT in Indonesia is commonly implemented in learning, especially after the publication curriculum 2013 (Akhlis \& Dewi, 2014). One example use of ICT is the application of games. Games as a medium in learning can be applied to deliver material for learning objectives can be achieved. Media in learning is an important component to help students achieve the learning objectives (Putra et al., 2019). Games can be differentiated based on a different period, namely traditional games and modern games. The traditional game is a game handed down from their ancestors played by ancient children with certain rules for obtaining excitement. Meanwhile, modern games are games that are played using technological tools such as smartphones, computers, iPads, and others. Games as learning media can be applied through games modern. This is due to the development of technology and to meet the demands of the modern era. Games are used as a learning media when they can develop cognitive and operational abilities such as solving the problem. Cognitive abilities are related to competence in differentiating objects, events, or stimuli and apply the rules as well as solve problems (Antunes et al., 2012). Games as a learning media make students have a different view of the material to be conveyed to motivate and involve the participants' students in material completion (Ziragawa et al., 2017). Games that are implemented in learning are called games education. Educational games are an educational method or tool that has educational characteristics (Ismail, 2009).

Based on the description above, one attempt to improve the well-being of students in the aspects of self-efficacy and curiosity is the use of games as a learning media that can provide independence for students in learning chemistry. Several things can be one of which affects the well-being of students is learning tedious and burdensome students. Therefore, innovation is needed in chemistry learning, namely the use of games as a learning medium. During the Covid-19 pandemic, the government made 
policy Merdeka Belajar. The use of computer-based games as a learning medium can give learners the freedom to learn only when at home. Besides, learning becomes fun and not burdens students. Games as learning media have an attractive appearance and can increase the feeling of comfort and reduce a sense of stress so that students can process information easily. The purpose of this study was to determine the relationship between the well-being of the participants' students and student learning outcomes in learning chemistry in the independent era learning, understanding the development of student learning outcomes after being applied games as a media of learning in the independent era of learning and knowing the response of students in the application of games as a learning media in the Merdeka Belajar era.

\section{Methods}

This study was designed using the One Group Pretest-Posttest Design that is, an experiment carried out in one group only without the other group being assigned comparison, with the following scheme (Sugiyono, 2016).

$$
01 \rightarrow \mathrm{X} 1 \rightarrow 02
$$

The research design is as follows.

01: Student well-being questionnaire and pre-test scores obtained before application of computer-based games as a learning media.

$\mathrm{X}$ : Treatment in the learning process of chemistry using thermochemical material computer-based games as a learning media.

02: Student well-being questionnaire and post-test scores obtained after application of computer-based games as a learning media.

This research was carried out in a high school in Gresik Regency, East Java class XI which consists of 33 odd semester students of the school year 2020/2021. The class selection was done randomly. The research instrument used a students' well-being questionnaire sheet, pretest and posttest sheets, and student response questionnaires. Student well-being questionnaires use a summated rating scale (Likert) with five choices, namely Strongly Agree, Agree, Doubt, Disagree, and Strongly Disagree. The results of the student well-being questionnaire will be analyzed using the Pearson Bivariate correlation test. Scoring criteria the student well-being questionnaire sheet instrument in Table 1.

Table 1. The Criteria for Scoring The Students' Well-being

\begin{tabular}{|c|c|}
\hline Answer & Score \\
\hline Strongly Agree & 5 \\
\hline Agree & 4 \\
\hline Doubt & 3 \\
\hline Disagree & 2 \\
\hline Strongly Disagree & 1 \\
\hline
\end{tabular}

Student well-being questionnaire sheets are given before and after games are applied as a media of learning. Then the questionnaire results are interpreted using a Likert scale score as in Table 2.

Table 2. Result Interpretation of Students' Well-being

\begin{tabular}{cc}
\hline Percentage & Category \\
\hline $0-20$ & Very Low \\
$21-40$ & Low \\
$41-60$ & Moderate \\
$61-80$ & High \\
$81-100$ & Very High \\
\hline
\end{tabular}

(Riduwan, 2015)

The pretest and posttest question sheets are in the form of multiple-choice questions totaling 10 pieces. Each correct number is assigned a value of 10 and if it is wrong then given a value of 0 . The test results will be analyzed through the paired sample T-test with a significance value of $5 \%$. Student response questionnaires refer to the outlined Guttman scale in the form of a question and given a choice of Yes or No. The response questionnaire contains 10 positive statements. Student response questionnaires are calculated based on the following criteria in Table 3. The data obtained will be analyzed using quantitative 
analysis with IBM SPSS Statistics 25. The results of data analysis are interpreted in the form of charts and tables.

Table 3. Guttman Scale Statement

\begin{tabular}{ccc}
\hline Answer & Score \\
\hline Yes/Agree & 1 & \\
No/Disagree & 0 & (Riduwan, 2015)
\end{tabular}

\section{Result and Discussion}

\section{Result}

The instrument used to retrieve data needs to be confirmed for its validity. The Student well-being questionnaire sheet has three aspects measured, namely the aspect of instructions, the aspect of language, and the aspect of objectives. The mode value obtained in the guidance aspect is 3 (feasible), the language aspect is 3 (feasible), and the objectives aspect is 3 (feasible). From the mode values above, it is found that the mode as a whole, namely 3. The student response questionnaire sheet has three measured aspects, namely aspects of instructions, aspects of language, and aspects of goals. The mode value obtained in the instructional aspect is 3 (feasible), the language aspect is 3 (feasible), and the objective aspect is 3 (feasible). From the above mode values, it is obtained that the mode is overall namely 3 . The pretest and posttest question sheets have three aspects that are measured, namely material aspects, construction aspects, and language aspects. The mode value obtained in the material aspect is 3 (feasible), the construction aspect is 3 (feasible), and on the language aspect is 3 (feasible). From the mode values above, it is found that the mode as a whole, namely 3.

\section{The Students' Well-being}

The student well-being questionnaire was applied to measure the opinions of students regarding self-efficacy (aspects of self-well-being) and curiosity in the learning of thermochemical material. In this questionnaire, there are 6 numbers for self-efficacy and 6 numbers for curiosity. This instrument applies the overall positive statement thus student answer options are given a score of $5,4,3,2$, and 1 . The higher the options the answers of students, the higher the well-being of students in aspects of self-efficacy and curiosity in chemistry learning. Getting lower Student answer options, the lower the student's well-being in the aspects of self-efficacy and curiosity in chemistry learning. Measuring the well-being of students using a questionnaire instrument was carried out before and after the application of the game as a learning media. It is used to compare the well-being of the participants' students before and after learning to apply games as media. The well-being of students is related to the learning outcomes of students. Then from that, to understand the relationship between the well-being of students and outcomes learning, the results of the questionnaire will be analyzed using the Bivariate Pearson correlation test. This parametric statistical test can be done because of the data obtained from the Likert scale categorized in the interval scale. This is because it is used to measure individual traits so that a total score can be obtained (Harpe, 2015). To carry out the correlation test, several test conditions must be implemented. First, the results of the well-being questionnaire were tested for Shapiro-Wilk normality because. In this data, the sample size is less than 50 (Hulu \& Sinaga, 2019). This test is used to detect whether the data is normally distributed or not. Data is normally distributed if a value is obtained significance $>0.05$ and the data are not normally distributed if a value is obtained significance $<0.05$ (Santoso, 2019).

Table 4. Normality Test Result

\begin{tabular}{lccc}
\hline & \multicolumn{3}{c}{ Shapiro-Wilk } \\
\cline { 2 - 4 } & Statistic & df & Sig. \\
\hline The students' well-being questionnaire result &, 973 & 33 &, 565 \\
The students pretest result &, 936 & 33 &, 051 \\
\hline
\end{tabular}

Based on Table 4, it is known that the Sig. for the results of the questionnaire the well-being of students is 0.565 and the value of Sig. for the participants' pretest results in students of 0.051 . Furthermore, the linearity test was done to determine the linear relationship between the two variables. The linear relationship can be identified if a value of Deviation from linearity Sig. is obtained $>0.05$ and there is no linear relationship between two variables if the value of Deviation from Linearity Sig. is obtained $<0.05$. 
Table 5. Linearity Test Result

\begin{tabular}{lllcc}
\hline & & & df & Sig. \\
\hline The students pretest result * The & Groups & (Combined) & 18 &, 815 \\
students' well-being questionnaire & & Linearity & 1 &, 094 \\
result & & Deviation from & 17 &, 919 \\
& & Linearity & & \\
& Within Groups & & 14 \\
& Total & & 32 \\
\hline
\end{tabular}

Based on Table 5, the Deviation from Linearity Sig. obtained amounting to 0.919 . After the data is declared normal and has a meaningful linear relationship between the two variables, then we tested the Pearson Bivariate correlation for determining the degree of relationship between the two variables expressed in the correlation coefficient. There is a correlation between the two variables if a value is obtained significance $<0.05$ and there is no correlation between the two variables if obtained significance value $>0.05$.

Table 6. Correlation Test Result

\begin{tabular}{|c|c|c|c|}
\hline & & $\begin{array}{c}\text { The students' well-being } \\
\text { questionnaire result }\end{array}$ & $\begin{array}{l}\text { The students } \\
\text { pretest result }\end{array}$ \\
\hline \multirow{4}{*}{$\begin{array}{l}\text { The students' well-being } \\
\text { questionnaire result-The } \\
\text { students pretest result }\end{array}$} & Pearson & 1 &, $355^{*}$ \\
\hline & Correlation & & \\
\hline & Sig. (2-tailed) & &, 043 \\
\hline & $\mathbf{N}$ & 33 & 33 \\
\hline
\end{tabular}

Based on Table 6, it is known that the significance value is 0.043 . The results of the student wellbeing questionnaire obtained before implementation games as learning media can be reviewed in Table 7 .

Table 7. The Distribution of Students' Well-being Before Game Implementation

\begin{tabular}{cc}
\hline Category & Frequency \\
\hline Very Low & 0 \\
Low & 0 \\
Moderate & 12 \\
High & 20 \\
Very High & 1 \\
\hline
\end{tabular}

Based on Table 7, the level of student well-being is obtained which can be grouped into very high, high, moderate, low, and very low. The number of students who have very high well-being in the aspect of self-efficacy and curiosity is 1 person, in the high category amounting to 20 people, in the moderate category there are 12 people, and none students who are categorized in low and very low well-being. The well-being level of learners can be shown in Figure 1. The results of the student well-being questionnaire obtained after the application games as learning media can be reviewed in Table 8 .

Table 8. The Distribution of Students' Well-being After Game Implementation

\begin{tabular}{cc}
\hline Category & Frequency \\
\hline Very Low & 0 \\
Low & 0 \\
Moderate & 4 \\
High & 23 \\
Very High & 6 \\
\hline
\end{tabular}

Based on Table 8, the level of student well-being is obtained which can be grouped into very high, high, moderate, low, and very low. The number of students who have very high well-being in the aspect of self-efficacy and curiosity there were 6 people, in the high category totaled 23 people, in the moderate category there were 4 people, and none students who are categorized in low and very low well-being. The well-being level of learners can be shown in the pie chart as follows figure 2. 


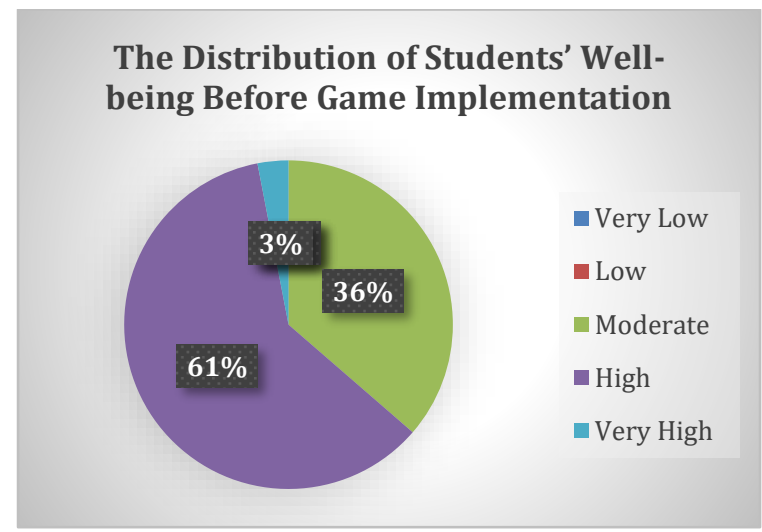

Figure 1. The Distribution of Students' Well-being Before Game Implementation

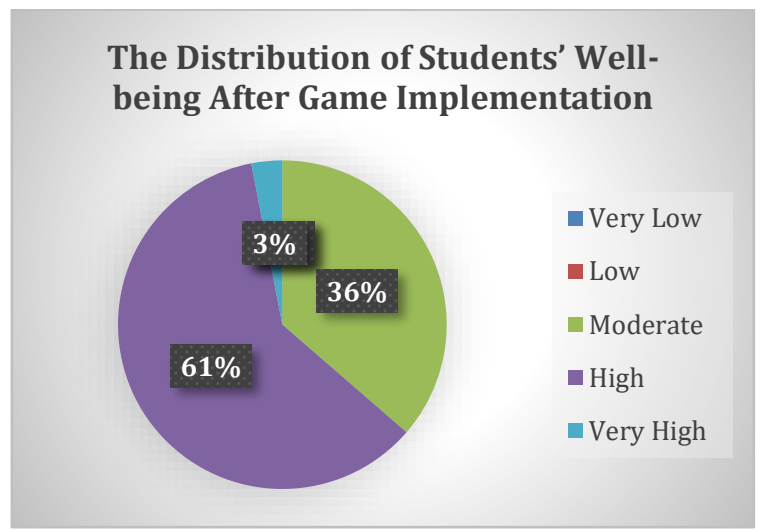

Figure 2. The Distribution of Students' Well-being After Game Implementation

To know that there is a significant increase in the students' well-being before and after the implementation of the game as learning media, it is necessary to test the paired sample T-test with a significance of 5\%. Before that, the data need to be stated as normally distributed. Therefore, The ShapiroWilk normality test is required because in this data, the number of samples less than 50 (Hulu \& Sinaga, 2019). This test is used to detect data that is normally distributed or not. Data is distributed normally if the significance value is obtained $>0.05$ and the data are not normally distributed if obtained a significance value $<0.05$ (Santoso, 2019).

Table 9. Normality Test Result of Students' Well-being

\begin{tabular}{lccc}
\hline & \multicolumn{3}{c}{ Shapiro-Wilk } \\
\cline { 2 - 4 } & Statistic & df & Sig. \\
\hline The Students' Well-being Before Game Implementation &, 973 & 33 &, 565 \\
The Students' Well-being After Game Implementation &, 967 & 33 &, 412 \\
\hline
\end{tabular}

Based on Table 9, it is known that the Sig. for the results of the questionnaire the well-being of students before the application of the game amounted to 0.565 and value Sig. for the results of the student well-being questionnaire after the application of the game amounting to 0.412. Furthermore, a paired sample T-test was performed with a significance of $5 \%$. Decision making in the paired sample T-test The test refers to the significant value that Ho is rejected and Ha is accepted if obtained significance value $<0.05$. If the significance value is obtained $>0.05$, then Ho is accepted and Ha was rejected (Santoso, 2019).

\section{The Students' Learning Outcomes}

Measurement of student learning outcomes using test sheet instruments namely the pretest which is carried out before and the posttest which is carried out after the application of games as a media of learning. This is to determine if there is a significant increase between test scores students before and after the implementation of the game as learning media, it is necessary to test the paired sample T-test with a significance of 5\%. Before that, the data need to be stated as normally distributed. Therefore, The ShapiroWilk normality test is required because in this data, the number of samples less than 50 (Hulu \& Sinaga, 2019). This test is used to detect data that is normally distributed or not. Data is distributed normally if the significance value is obtained $>0.05$ and the data are not normally distributed if obtained a significance value $<0.05$ (Santoso, 2019).

Table 10. Normality Test Result of Students' Learning Outcomes

\begin{tabular}{lccc}
\hline & \multicolumn{3}{c}{ Shapiro-Wilk } \\
& Statistic & df & Sig. \\
\hline The students pretest result &, 936 & 33 &, 051 \\
The student's posttest result &, 955 & 33 &, 186 \\
\hline
\end{tabular}

Based on Table 10, it is known that the Sig. for the participants' pretest results from students of 0.051 and the Sig. for students' posttest results of 0.186 . Furthermore, a paired sample T-test was performed with a significance of $5 \%$. Decision making in the paired sample T-test The test refers to the 
significance value that $\mathrm{Ho}$ is rejected and $\mathrm{Ha}$ is accepted if obtained significance value $<0.05$. If the significant value is obtained $>0.05$, then Ho is accepted and Ha was rejected (Santoso, 2019).

\section{The Students' Responses}

The response of students to the application of the game as a learning media measured by a response questionnaire. Student response is categorized as positive if $\geq 60 \%$ choose the option to agree. Response questionnaire results for students can be reviewed in Table 11.

Table 11. The Result of Student Response Questionnaire

\begin{tabular}{|c|c|c|c|}
\hline Point & Category & Agree Percentage & Category \\
\hline 1 & $\begin{array}{l}\text { The Legend of Thermo game can make learning from } \\
\text { home become more comfortable and relaxed }\end{array}$ & $100 \%$ & Positive \\
\hline 2 & $\begin{array}{l}\text { Learning and play The Legend of Thermo can make } \\
\text { learning anytime and anywhere }\end{array}$ & $76 \%$ & Positive \\
\hline 3 & $\begin{array}{l}\text { The Legend of Thermo game makes it easy to } \\
\text { understand the material }\end{array}$ & $91 \%$ & Positive \\
\hline 4 & $\begin{array}{l}\text { Thermochemical material is easy to understand after } \\
\text { playing The Legend of Thermo }\end{array}$ & $79 \%$ & Positive \\
\hline 5 & $\begin{array}{l}\text { Posttest question is easy to do after playing The Legend } \\
\text { of Thermo }\end{array}$ & $70 \%$ & Positive \\
\hline 6 & Questions in The Legend of Thermo is easy & $76 \%$ & Positive \\
\hline 7 & $\begin{array}{l}\text { The Legend of Thermo game is recommended to } \\
\text { friends who never played while studying }\end{array}$ & $97 \%$ & Positive \\
\hline 8 & Desire to play othe games for the learning process & $88 \%$ & Positive \\
\hline 9 & $\begin{array}{l}\text { Feel easy and not burdened in operating The Legend of } \\
\text { Thermo }\end{array}$ & $82 \%$ & Positive \\
\hline 10 & $\begin{array}{l}\text { Fid it easy to understand game rules and game } \\
\text { completion steps in The Legend of Thermo }\end{array}$ & $88 \%$ & Positive \\
\hline
\end{tabular}

From the table 11, it is found that all aspects have a percentage agree $\geq 60 \%$. Students are given a week to apply games as learning media. During that time, 10 students play 3 times, 8 students play 2 times, and 15 students play 1 time. Apart from playing games as a learning media at home, students also carry out activities to support learning such as reading books, discussions with friends, and watching learning videos. Percentage of $55 \%$ of students who read books to support learning, discussion with friends $48 \%$, and watching learning videos $27 \%$.

\section{Discussion}

Instruments validation and review are needed first before it is used. The process of reviewing and validating the instruments was carried out by 2 chemistry lecturers who are experts in their fields and 1 chemistry teacher. The instrument that was reviewed and validated was a students' well-being questionnaire, pretest and posttest sheets, and student response questionnaires. Validation of the device uses a Likert scale with 5 choices, namely $0=$ very poor, $1=$ poor, $2=$ sufficient, $3=$ feasible, and $4=$ very feasible. Result validation is categorized on an ordinal scale. Therefore, this data is not based on parametric statistics. On an ordinal, median, or mode scale are applicable statistics. Including errors, if this scale is analyzed by parametric statistics (Kuzon et al., 1996). The students' well-being questionnaire, student response questionnaire, and pretest and posttest question sheets have the same mode values, namely 3. This shows that all of the instruments are categorized as feasible to be used as an instrument in data collection.

\section{The Students' Well-being}

The significance value obtained from the Pearson Bivariate test is $0.043<0.05$ indicates a correlation between the two variables. Based on the calculation of the correlation coefficient formula, the price of $r=0.36$. The value of $r$ obtained is positive, so it can be concluded that there is a positive correlation between the two variables (Sudjana, 2005). Based on the explanation above, it can be summarized that the well-being of students positively correlated with the learning outcomes of students. In other words, if the students' well-being is high, it can improve student learning outcomes. The result of the students' well-being questionnaire can be summarized that the participants' majority of students have high well-being in learning chemistry before application of the game as a learning media with a percentage of $61 \%$. Meanwhile, the result of students' well-being questionnaire after application of the game as a learning medium can be 
summarized that the participant's majority of students have high well-being in learning chemistry with a percentage of $70 \%$. From the results of the students' well-being obtained, it can be proven that the wellbeing of students has increased. Participant well-being of students before the implementation of the game is categorized as high by percentage $61 \%$ while the well-being of students after the implementation of the game is categorized as high with a percentage of $70 \%$. The application of the game has been proven to have a positive effect on well-being, personal growth, stress, and anxiety (Dennis \& O'Toole, 2014). The use of games (gamification) can foster influence, behavior, cognition, user experience, and have a positive influence on health and well-being (Johnson et al., 2016). Gamification can improve well-being and generate positive experiences of satisfaction of basic psychological needs and other aspects of well-being such as positive emotions, involvement, relationships, meaning, and achievements.

Games as learning media can enable students to see the material differently to motivate and involve students in material completion (Ziragawa et al., 2017). Games can give a distinct impression in the memory of students as well provide a pleasant learning atmosphere without leaving learning objectives (Roestiyah, 2001). Learning fun provides a sense of comfort, and not overload can increase the well-being of students in the aspects of curiosity and self-efficacy. The game has attractive visuals and challenges to be completed so that students feel challenged and continue to want to explore more deeply about the material being taught. The application of games as a learning media is one of the innovations in implementing learning at home in the era of the Covid-19 pandemic to give students the independence to study anywhere and anytime. With games, students are given the freedom to determine the time and place of study independently. Theory chemistry is packed in a game with an attractive virtual so that participants do not feel burdened and feel comfortable when studying.

\section{The Students' Learning Outcomes}

The pretest and posttest are used to compare the learning outcomes of students before and after learning using games as a media. Student learning outcomes result from several aspects, one of which is the well-being of students. Increasing the well-being of students can increase academic achievement either directly or indirectly. For example, the level of well-being positively influences academic achievement with increased motivation, engagement, attendance, and reduced behavior problems (Noble \& Wyatt, 2008). The normality result is showed the Sig. both> 0.05 then it can be summarized that the result data the pretest and posttest of students were normally distributed. Furthermore, a paired sample T-test using SPSS obtain the value of significance is 0.002 . Significance value $0.002<0.05$, it can be decided that Ho was rejected and Ha accepted. So that it can be summarized that there is a significant difference between the acquisition of students' pretest with students' posttest. Based on the results above, there is a significant influence positive on the learning outcomes of students after the application of the game as learning Media. The results obtained were uniform with the research which confirms that student learning outcomes can increase after implementing the game as a learning media and make students feel that learning chemistry is fun (Lutfi et al., 2019). Result in pretest increases from the posttest results following the theory namely the increase in the well-being of students improves academic achievement, either directly or indirectly (Noble \& Wyatt, 2008).

\section{The Students' Responses}

The percentage agree is more than $60 \%$ indicated that the participants' responses to students on the application of games as learning media are categorized positively. Learners' positive feedback is supported by the results of the posttest that increased from the pretest results before applying the game as a learning medium. The appearance of an attractive computer-based game makes students interested in playing until they can finally learn the chemistry of the games played (Agarwal \& Saha, 2011). Besides learning using games as media, students also carry out activities such as reading a book, discussing with friends, and watching learning videos that support the development of learning outcomes. It is uniform with the concept of independent learning initiated by the Ministry of Education and Culture, namely learning by maximizing more technology so that students can optimally improve their talents and interests

\section{Conclusions and Suggestions}

Students' well-being is positively correlated with student learning outcomes in chemistry learning in the independent learning era. Then it can be summed up that implementation of the game as a learning media can develop the well-being of students. Improved participant learning outcomes for students who are shown through the pretest and posttest test show that there is a significant difference between students' pretest and posttest results learners. The increased pretest results from the posttest results were due to increasing the well-being of students to increase academic achievement, either directly or indirectly. The 
results of the well-being of students in this study are limited in aspects of self-efficacy and curiosity. Therefore, further study is needed regarding measuring the well-being of students in all aspects or aspects of others in chemistry studies.

\section{References}

Abidah, A., Hidaayatullaah, H. N., Simamora, R. M., Fehabutar, D., \& Mutakinati, L. (2020). The Impact of Covid-19 to Indonesian Education and Its Relation to the Philosophy of "Merdeka Belajar." Studies in Philosophy of Science and Education, 1(1), 38-49. https://doi.org/https://doi.org/10.46627/sipose.v1i1.9.

Agarwal, M., \& Saha, S. (2011). Learning Chemistry Through Puzzle Based Game: Atoms to Molecule. International Conference on Emerging E-Learning Technologist and Applications, 189-193.

Akhlis, I., \& Dewi, N. R. (2014). Pengembangan Perangkat Pembelajaran Science Berorientasi Cultural Deviance Solution Berbasis Inkuiri Menggunakan ICT untuk Mengembangkan Karakter Peserta Didik. Jurnal Pendidikan IPA Indonesia, 3(1), 86-94.

Alberti, E. T., \& Witryol, S. L. (1994). The Relationship between Curiosity and Cognitive Ability in Third- and Fifth-Grade Children. The Journal of Genetic Psychology: Research and Theory on Human Development, 155(2), 129-145. https://doi.org/10.1080/00221325.1994.9914767.

Alsumait, A., \& Al-Musawi, Z. S. (2013). Creative and Innovative E-learning using Interactive Storytelling. International Journal of Pervasive Computing and Communications, 9, 209-226. https://doi.org/10.1108/IJPCC-07-2013-0016.

Antunes, M., Pacheco, M., \& Giovanela, M. (2012). Design and Implementation of an Educational Game for Teaching. Journal of Chemical Education, 89(4), 517-521. https://doi.org/10.1021/ed2003077.

Awartani, M., Whitman, C. V, \& Gordon, J. (2008). Developing Instruments to Capture Young People's Perceptions of How School as a Learning Environment Affects Their Well-Being. European Journal of Education, 43(1), 51-70. https://doi.org/10.1111/j.1465-3435.2007.00337.x.

Bandura, A. (2006). Toward a Psychology of Human Agency. Perspective on Psychological Science, 1(2), 164180. https://doi.org/10.1111\%2Fj.1745-6916.2006.00011.x.

Cahill-Solis, T. L., \& Witryol, S. L. (1994). Children's Exploratory Play Preferences for Four Levels of Novelty in Toy Constructions. Genetic, Social, and General Psychology Monographs, 120(4), 394-408. https://psycnet.apa.org/record/1995-24644-001.

Dennis, T. A., \& O'Toole, L. J. (2014). Mental health on the go: Effects of a gamified attention-bias modification mobile application in trait-anxious adults. Clinical Psychological Science, 2(5), 576-590. https://doi.org/10.1177\%2F2167702614522228.

Fraillon, J. (2004). Measuring Student Well-Being in the Context of Australian Schooling: Discussion Paper. Curriculum Corporation.

Harpe, S. E. (2015). How to Analyze Likert and Other Rating Scale Data. Currents in Pharmacy Teaching and Learning, 7(6), 836-850. https://doi.org/10.1016/j.cptl.2015.08.001.

Hasan, N., \& Bao, Y. (2020). Impact of "e-Learning crack-up" perception on psychological distress among college students during COVID-19 pandemic: A mediating role of "fear of academic year loss." $\begin{array}{lllll}\text { Children and Youth } & \text { Services }\end{array}$ https://doi.org/10.1016/j.childyouth.2020.105355.

Hulu, V. T., \& Sinaga, T. R. (2019). Analisis Data Statistik Parametrik Aplikasi SPSS dan Statcal. Yayasan Kita Menulis.

Ismail, A. (2009). Education Games Menjadi Cerdas dan Ceria dengan Permainan Edukatif. Pilar Media.

Johnson, D., Deterding, S., Kuhn, K. A., Staneva, A., Stoyanov, S., \& Hides, L. (2016). Gamification for Health and Wellbeing: A Systematic Review of The Literature. Internet Interventions, 6, 89-106. https://doi.org/10.1016/j.invent.2016.10.002.

Kristiawan, M., Aminudin, N., \& Rizki, F. (2021). Optimalisasi Pembelajaran Daring Berbasis Aplikasi Online bagi Calon Guru Pendidikan Anak Usia Dini. Jurnal Obsesi : Jurnal Pendidikan Anak Usia Dini, 5(2), 1905-1914. https://doi.org/10.31004/obsesi.v5i2.942.

Kuzon, W. J., Urbhanchek, M., \& McCabe, S. (1996). The Seven Deadly Sins of Statistical Analysis. Annals of Plastic Surgery, 37(3), 265-272. https://doi.org/10.1097/00000637-199609000-00006.

Lau, N., \& Hue, M. (2011). Preliminary Outcomes of a Mindfulness-Based Programme for Hong Kong Adolescents in Schools: Well-Being, Stress and, Depressive Symptoms. International Journal of Children's Spirituality, 16(4), 315-330. https://doi.org/10.1080/1364436X.2011.639747.

Litman, J. A., \& Jimerson, T. L. (2004). The Measurement of Curiosity As a Feeling of Deprivation. Journal of Personality Assessment, 82(2), 147-157. https://doi.org/10.1207/s15327752jpa8202_3.

Lutfi, A., Suyono, S., Erman, E., \& Hidayah, R. (2019). Edutainment with computer game as a chemistry 
learning media. JPPS (Jurnal Penelitian Pendidikan Sains), 8(2), 1684-1689. https://journal.unesa.ac.id/index.php/jpps/article/view/5103.

Müller, A. M., Goh, C., Lim, L. Z., \& Gao, X. (2021). COVID-19 Emergency eLearning and Beyond: Experiences and Perspectives of University Educators. Education Sciences, 11(1), 19. https://doi.org/10.3390/educsci11010019.

Naparin, M., Rusmansyah, \& Almubarak. (2020). Identifikasi Kemampuan Berpikir Kritis dan Efikasi Diri Siswa SMA Negeri Kelas XI IPA Sekota Banjarmasin pada Materi Laju Reaksi. JCAE, Journal of Chemistry And Education, 3(3), 106-117. https://doi.org/10.20527/jcae.v3i3.425.

Noble, T., \& Wyatt, T. (2008). Scoping Study into Approaches to Student Wellbeing: Literature Review. Australian Catholic University and Erebus International.

Nuraeni, S., Feronika, T., \& Yunita, L. (2019). Implementasi Self-Efficacy dan Keterampilan Berpikir Kritis Siswa Pada Pembelajaran Kimia di Abad 21. Jambura Journal of Educational Chemistry, 1(2), 49-56. https: //doi.org/10.34312/jjec.v1i2.2553.

Pamungkas, M. S., Mulyani, S., \& Saputro, S. (2017). Penerapan Model Pembelajaran POE dengan Metode Praktikum untuk Meningkatkan Rasa Ingin Tahu dan Prestasi Belajar Kimia Siswa. PAEDAGOGIA, Jurnal Penelitian Pendidikan, 20(1), 46-60. https://doi.org/10.20961/paedagogia.v20i1.16596.

Prihastoto, R., Ashadi, \& Haryono. (2019). Penerapan Model Pembelajaran Learning Cycle 5E untuk Meningkatkan Rasa Ingin Tahu dan Prestasi Belajar Siswa pada Materi Kesetimbangan Kimia Kelas XI Semester Ganjil SMA Negeri 1 Teras Tahun Pelajaran 2015/2016. Jurnal Pendidikan Kimia, 8(1), 110-115. https://doi.org/10.20961/jpkim.v8i1.22918.

Putra, I. N., Kartini, K. S., \& Widiyaningsih, N. N. (2019). Implementasi Media Pembelajaran Interaktif Berbasis Mobile pada Materi Hidrokarbon. Jurnal Pendidikan Kimia Indonesia, 4(2), 43-52. https://doi.org/10.23887/jpk.v4i2.28536.

Rasmitadila, Samsudin, A., \& Prasetyo, T. (2019). Teacher-students' instructional interactions analysis (TSIIA): A case study in inclusive English classrooms in Indonesia. International Journal of Interdisciplinary Educational Studies, 14(1), 1-22. https://doi.org/10.18848/2327011X/CGP/v14i01/1-22.

Riduwan. (2015). Skala Pengukuran Variabel-variabel Penelitian. Alfabeta.

Roestiyah. (2001). Strategi Belajar Mengajar. Rineka Cipta.

Santoso, S. (2019). Menguasai SPSS Versi 25. Elex Media Komputindo.

Stajkovic, A. D., \& Luthans, F. (1998). Self-efficacy and work-related performance: A meta-analysis. Psychological Bulletin, 124(2), 240. https://psycnet.apa.org/doi/10.1037/0033-2909.124.2.240.

Sudjana. (2005). Metoda Statistika. Tarsito.

Sugiyono. (2016). Statistika untuk Penelitian. Alfabeta.

Susilana, R., Herlina, \& Hadiapurwa, A. (2020). Pengembangan Website Pelatihan Program Intervensi Mandiri (PIMC) bagi Orangtua Anak Penyandang Autisme. Pedagogia Jurnal Ilmu Pendidikan, 18(02), 173-187. https://doi.org/https://doi.org/10.17509/pdgia.v18i2.31424.

Tauhid, S. M., Foldra, F., Jayawinangun, R., \& Pakuan, U. (2020). Trend Kajian Pembelajaran Daring : Suatu Telaah Pustaka. Jurnal Penelitian Sosial Ilmu Komunikasi, 4(September), 157-164.

Wilson, A. (2020). Penerapan Metode Pembelajaran Daring (Online) melalui Aplikasi Berbasis Android saat Pandemi Global. SAP (Susunan Artikel Pendidikan), 5(1). https://doi.org/10.30998/sap.v5i1.6386.

Ziragawa, V. S., Olusanya, A. I., \& Maduku, T. (2017). Gaming in Education: Using Game as a Support Tool to Teach History. Journal of Education and Practice, 8(15), 55-64. https://eric.ed.gov/?id=EJ1143830. 